\title{
Anomalies of the Housing Market in Albania
}

\author{
Bitila Shosha $^{1, *}$, Armela Anamali ${ }^{1}$, Alma Zisi $^{2}$ \\ ${ }^{1}$ Department of Finance and Accounting, "Aleksander Moisiu" University, Business Faculty, Durrës, Albania \\ ${ }^{2}$ Department of Economic Sciences, "Aleksander Moisiu" University, Business Faculty, Durrës, Albania
}

Received February 17, 2021; Revised April 26, 2021; Accepted May 11, 2021

\section{Cite This Paper in the following Citation Styles}

(a): [1] Bitila Shosha, Armela Anamali, Alma Zisi , "Anomalies of the Housing Market in Albania," Universal Journal of Accounting and Finance, Vol. 9, No. 3, pp. 275 - 284, 2021. DOI: 10.13189/ujaf.2021.090301.

(b): Bitila Shosha, Armela Anamali, Alma Zisi (2021). Anomalies of the Housing Market in Albania. Universal Journal of Accounting and Finance, 9(3), 275 - 284. DOI: 10.13189/ujaf.2021.090301.

Copyright $\subseteq 2021$ by authors, all rights reserved. Authors agree that this article remains permanently open access under the terms of the Creative Commons Attribution License 4.0 International License

\begin{abstract}
The real estate sector is one of the most important sectors of the economy for developing countries. The housing market is directly related to the performance of economy. The impact of this market is measured through the volume of various transactions, such as real estate sales, lease contracts, construction contracts, import transactions, foreign exchange, transactions of financial intermediaries and real estate agencies, employment contracts, etc. The real estate market is directly influenced by housing policies, the level of financial system development, visible additional costs (tax rates and credit costs) and its invisible costs (which is informality and information asymmetry). Hypotheses: The housing market operates according the rules of the supply-demand and the factors that affect the fluctuation of housing prices. The purpose of the article is to evaluate the demand factors in the performance of house prices in Albania. Methodology: The study employs an exploratory analysis based on the literature review, the secondary data and empirical analysis. The authors make a comparison between the factors identified by the literature review, the analysis of the secondary data for the Albanian real estate market, and statistical relationships of individual factors as well: GDP/capita, Exchange rate, Interest rates in ALL, Interest rates EURO, Remittances and the level of mortgage loans in EURO. In the conclusions of the paper, some of the factors that have directly influenced the fluctuations in real estate prices in Albania are: the demand and the supply of real estate; the change in the value of the functional currency; state intervention through fiscal policies and urban planning; credit financing to businesses and individuals, etc.
\end{abstract}

Keywords Housing Market, Interest Rate, Exchange Rate, Mortgage Loan, Remittances, Real Estate, Prices,
Albania, Fiscal Policy, Anomalies

JEL: D14, R21, R31, R39

\section{Introduction}

The Albanian housing market is an informal market. In the last two decades, Albania had a strong socio-economic development, which had a direct impact on the performance of prices in this market, such as population movement, law enforcement, foreign direct investment, remittances, building permits and legalization of illegal construction, the effects of the financial crisis of 2008, etc. The direct comparison method and the rental capitalization method have yielded very different results [1], since the real estate market began to function after the 1990s. In his analysis, the author concludes that the apartments which have an average market price of $1000-1200$ euro $/ \mathrm{m}^{2}$ have approximately the value at the average construction cost of 375-430 EUR $/ \mathrm{m}^{2}$. In one of their study, [2], model housing prices, mainly from a demand perspective, are impacted by the following factors: personal income per capita, population, employment, unemployment rate, housing stock and interest rate on mortgage loans. [3] Argue that the rise in house price is largely attributable to fundamental market factors, in particular, rising incomes and falling interest rates. [4] Points out that rather than lowering long-term interest rates, it was the introduction of new forms of financing and the lack of oversight, which contributed to the rapid rise in house prices. In their study, [5] show that the ratio of house price to income per capita (19.4) is among the highest compared to the region and 
western developed countries. This high indicator tells us that house prices which are very high compared to the average income of the family. This effect has generally been created in the housing and real estate market [5]. The effect of house prices can arise if (i) many individuals want to buy a home today (putting upward price pressure) because they expect home prices to rise in the coming period and (ii) these expectations are not based on the underlying principles [6]. Estimating house prices is a difficult task due to the uncertainty and incomparability of transactions and the heterogeneity that characterizes the products of this market not only within the sector but also over time. The lack of price data even their reliability, make it difficult to assess price performance [7]. House Price Index coefficients appear positive, sometimes negative, making their interpretation difficult [8].

\section{The Purpose of This Study}

To understand how the housing market works, a descriptive analysis of the main factors affecting the demand for housing will be carried out. According to [9], the change in demand for housing comes as a result of price and factors other than price such as: economic growth, interest rates, bank lending, demographic trends and expectations for the future. The paper has the purpose of conducting a descriptive analysis of the demand factors in the performance of house prices in Albania, based on a literature review and secondary source data obtained from the Bank of Albania, the Institute of Statistics, the World Bank, etc.

\section{Methodology}

The realization of this study begins with a literature review of the factors that determine the price of the housing. The nature of the review is exploratory, as the housing market and the price-determining factors are specific to different countries. The determining factors in the price of flats are grouped into macroeconomic (national and regional) and microeconomic. The rest of the paper is a descriptive analysis of Albania's housing market and price fluctuations in the last decade. Secondary data from sources such as Bank of Albania, Institute of Statistics, World Bank, etc. were used for the analysis of the Albanian market. The changes in house prices can be caused by a variety of factors that may affect, such as supply and demand for housing [10]. The scheme set up by [11], reflects the relationship between the housing market, policies, factors influencing the demand, the supply and the price of the housing. The offer is influenced by the flow of existing housing services, the condition and quality of existing housing, as well as new construction. Housing is subject to the influence of some external factors such as economic growth, inflation and the lending system. According to the scheme of factors that determine the performance of the housing market used as the main methodology, in this paper only the demand factors that influence the price of housing, the level of employment, the demographic trend and the income from emigration are examined.

\section{Determinants of Demand for Housing}

The main factors affecting the house price are: interest rate on the loan, mortgage loan, exchange rate, GDP per capita and the role of remittances. Let us deal with the above factors in turn.

\subsection{Credit Interest Rate}

The change in interest rates has a direct impact on the capital used for construction [12], but also on the investment costs of purchasing the house. Home purchase loans account for about $61 \%$ of the total individual loans (Credins Bank, 2019) ${ }^{1}$. In the period 2014-2018(referring Figure no. 1), we note that there are interest rate fluctuations for both in ALL (Albanian currency) and Euro loans.

In February 2018, the home loan rate reached the lowest value of $3.64 \%$ while the lowest rate for euro loans is in 2017 of $2.93 \%$. Loans for financing real estate purchases are a relatively secure form of lending, for the collateral they carry. Moreover, in an environment of declining interest rates, which keeps mortgage servicing costs are more and more within the budget ceilings of households supported by current income, it usually increases the demand for residential real estate [13]. Hence, the fall in interest rates leads to an increase in the demand for houses and consequently the market price of residential real estate.

\subsection{Lending to Finance Housing Purchases}

Another factor, which has received special attention in the literature, is the mortgage loan, which affects the price of housing. The present study has taken on particular significance for the very implications it has on the two important sectors of the economy (in the construction and banking sectors), as well as the direct or indirect consequences that these sectors have on the overall economy and financial stability in the country. Mortgage loans affect house prices through the so-called financial incentive mechanism. According to [14] the financial incentive mechanism consists of the self-reinforcing

${ }^{1}$ https://bankacredins.com/wp-content/uploads/2019/05/Raportimi-i-trans parences-per-12-mujorin-e-mbyllur-me-31.12.2018-1.pdf 
phenomenon of the relation of credit to house prices. Thus, the credit given by banks promotes the demand for home purchase. In response to the increased demand, house prices will rise, while the collateral pledged to get the loan will increase, enabling additional housing loans to be provided, thereby further boosting the demand for loans and speeding up the process. [15], for the period 1998-2010, estimate the relationship between house prices and mortgage loans with the DOLS method. These two indicators turn out to be positively and mutually affecting each other. Also, it is estimated that mortgage loans are positively related to income and negatively to interest rates. Bank of Albania data, as shown in Figure no. 2, infer that home loans to households increased by $3 \%$ for the 9 -month period 2017, compared to the same period earlier. Sources from commercial banks indicate that the average home loan amount is 50,000 euro. Middle-income individuals can buy an apartment that costs around 100.000 euro, where the square meter does not exceed 1.100 euro. On the other hand, luxury apartments can hardly be financed through bank loans. What is evident from the Bank of Albania data is that the home loan in domestic currency increased by $10 \%$ for the 9 months of the year. The credit stock in ALL is about ALL 476 billion. The home loan denominated in the single European currency, unlike the ALL (Albania Currency), has contracted slightly over these 9 months, at 3\% compared to a year earlier.
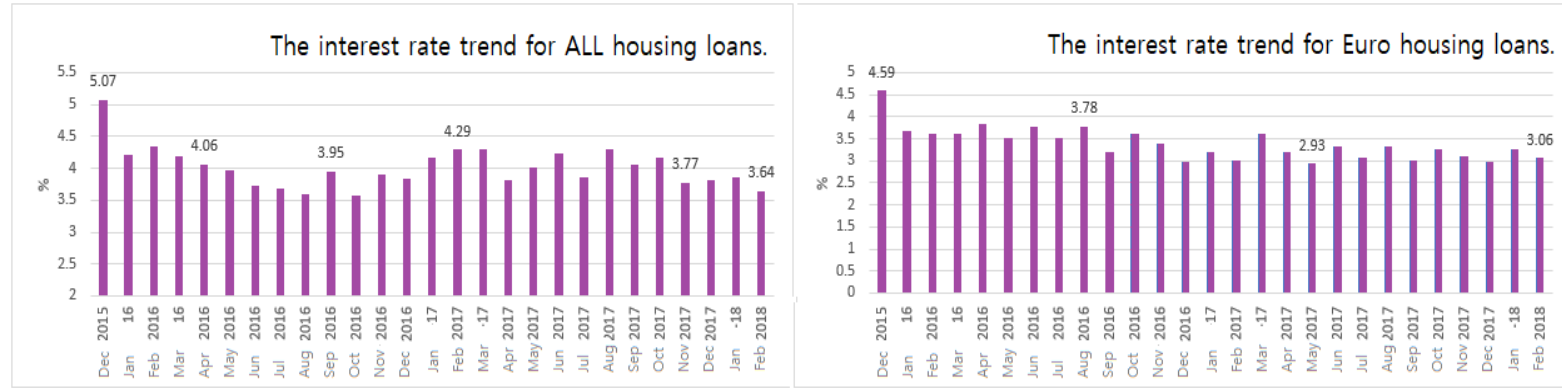

Source: Bank of Albania, 2018

Figure 1. Trend of interest rates in ALL and euro for loans for house purchase

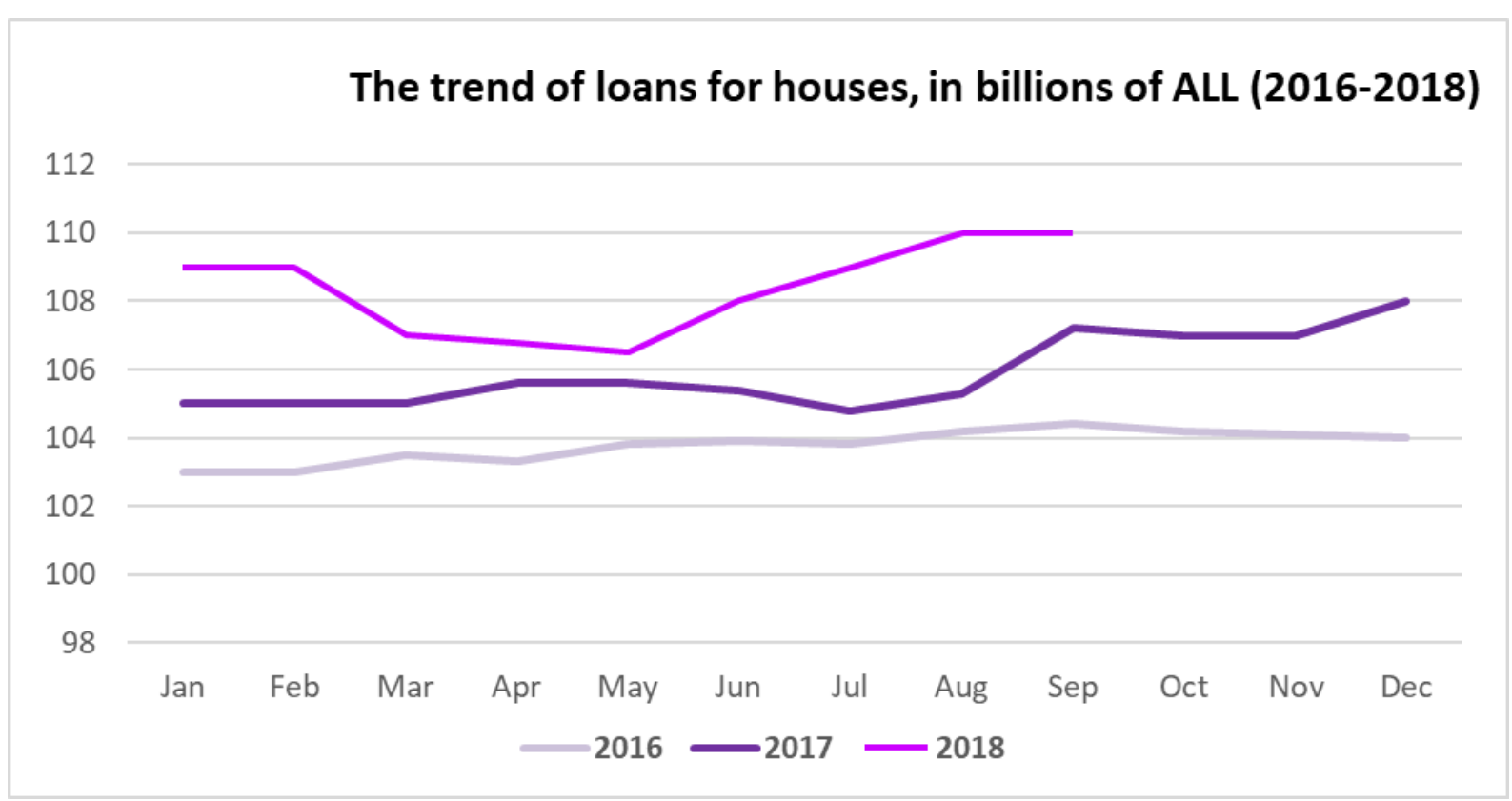

Source: Bank of Albania, 2018

Figure 2. Trend of loans for house purchasing during 2016-2018 (in billions ALL) 


\subsection{Exchange Rate}

The exchange rate is another factor affecting the housing market, especially for those countries that use foreign currency in their economy. The real estate market in Albania is a market characterized by the high use of the Euro currency. A stable foreign exchange rate enhances the security of the ability to repay the loan obligations also on the value of the real estate. [16], her study concludes that the depreciation of the national currency (ALL) against the Euro increases the demand for housing and the price of the housing market, as the housing market is characterized by transactions in the Euro.

In conclusion, there are some similarities to the authors [17] and [18]. From the charts hereinafter (in Figure no. 3) we can see that the euro has depreciated during the period December 2015-June 2019, although this has not been much felt in housing lending. Euro-denominated loans continue to account for over $80 \%$ of the total individual loans (and NPOs serving individuals).

But how has the depreciation of the euro affected the demand for housing? In order to determine the impact of the depreciation of the euro, we must specify the income received by the majority of Albanian citizens. Given that most payments are in ALL, the depreciation of the euro will have a positive impact on the increase in demand for housing (given that the sale price of houses is in euro per square meter). The depreciation of the euro has a positive effect on the credit system as a large part of the loans in Albania are in the euro currency while the borrowers' income and main activities are denominated in ALL. The depreciation of the euro will not have the same effect on emigrant housing demand, as they now need a larger number of euro to buy the same home.

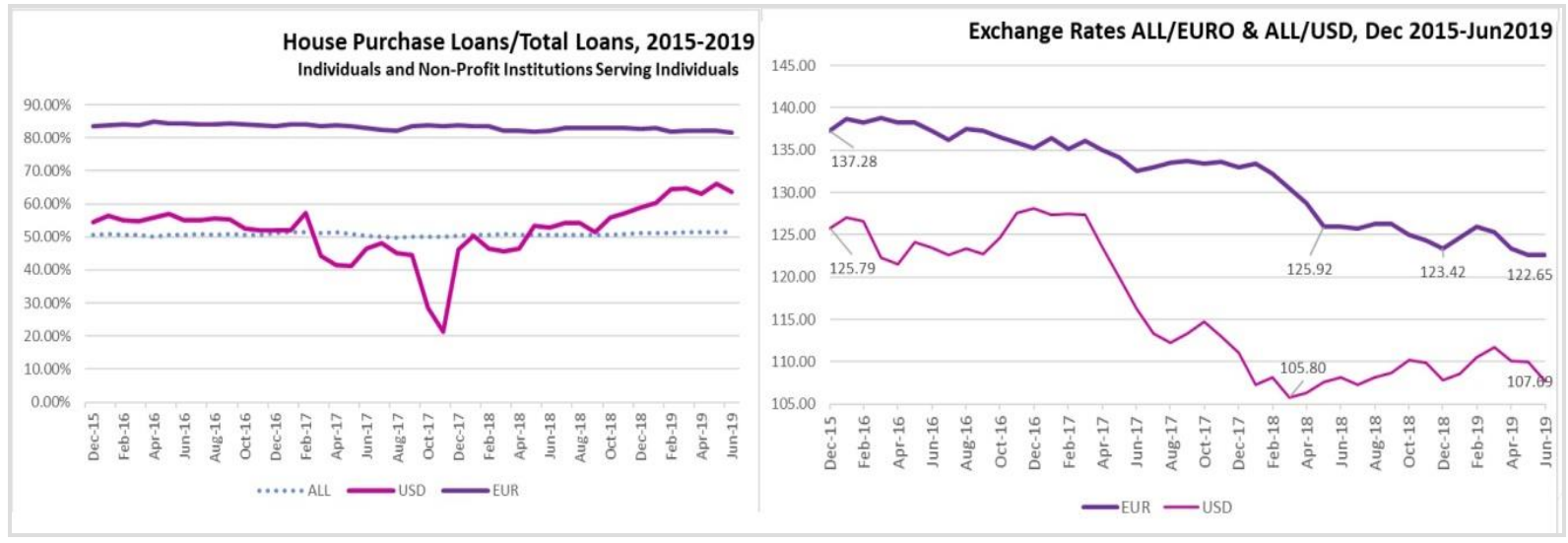

Source: Bank of Albania,20194 (Authors's Calculations)

Figure 3. The performance of home loans and exchange rates for the two major currencies

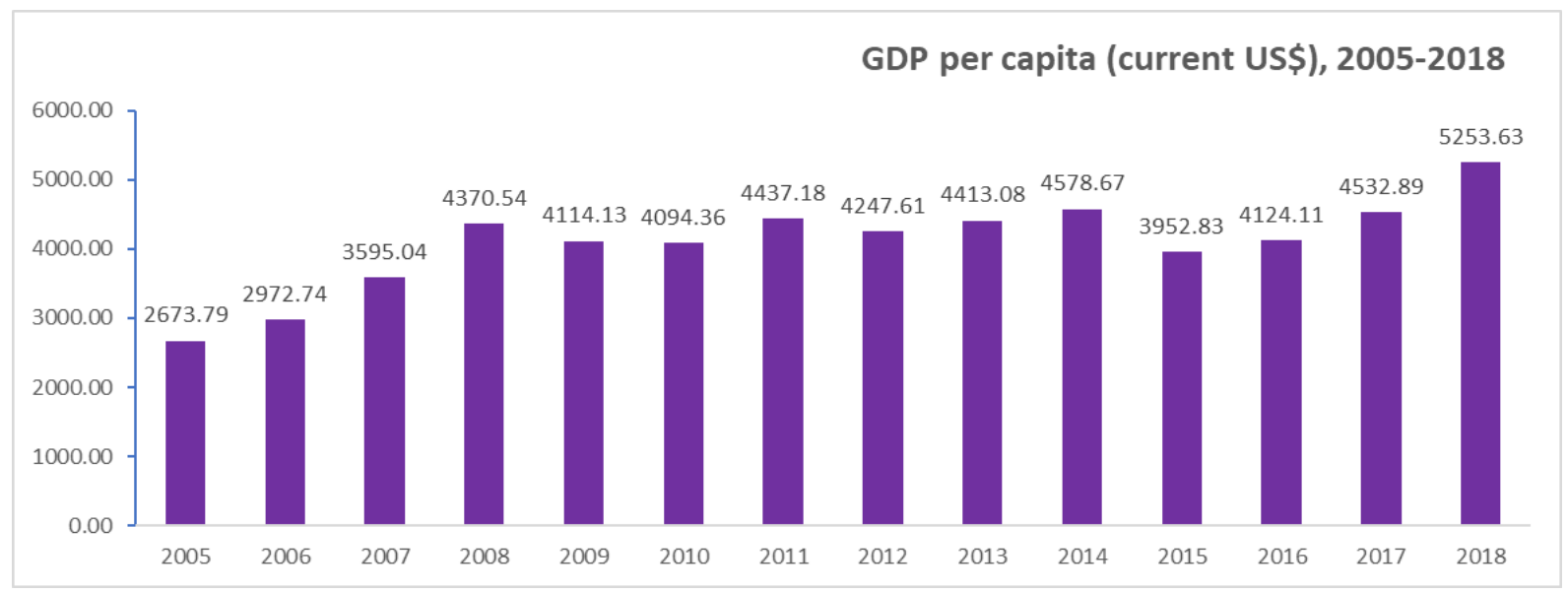

Source: World Bank, $2019^{5}$

Figure 4. The trend of GDP/Capita during 2005-2018 


\subsection{Gross Domestic Product (GDP/Capita)}

The size of the investment in real estate is influenced by the economic performance and the increase of disposable income of the citizens, which also results in the increase of the demand for real estate. The importance of economic growth in the performance of the construction sector is related to the demand for residential housing.

[19] Their paper finds that the rapid rise in house prices in the CSEE countries was positively influenced by strong economic growth, real wage growth combined with high demand for housing and accompanied by financing abundant with loans from the banking system. [20], his empirical study of the relationship between credit and current economic activity shows that the annual rate of change in real credit is closely linked to that of real GDP. [21] Their study shows that there is a positive relationship between GDP and lending activity, arguing that higher economic growth allows all economic agents to borrow more in order to finance their consumption and home investment. The factor which affects the reduction of credit demand is the expectations that consumers have when they believe that the price of housing in the coming period will decrease, causing the demand for housing to decrease in the current period and increase in the period next. The Figure no. 4 shows that GDP per capita after 2015 has been rising. There is a significant increase in GDP per capita from 2017 to 2018. This will also have a positive impact on housing demand. It is noted that housing construction has also been increasing in recent years mainly in the city of Tirana.

\subsection{Remittances}

In his study, [1] concludes that the large difference between the values of the comparison method and that of rental capitalization is explained by the existence of income other than wages in Albanian households. According to the Bank of Albania, Figure no. 5, remittances reached a value of 670 million euro in 2018, marking an increase of $5.3 \%$ compared to the previous year. This is the highest level since 2012, while a year later in 2013, emigrant remittances reached their lowest level since the 1990s, down to 545 million euro. But after 2013, remittances began to rise again to reach 2018 , where growth in absolute value was about 34 million euro, the highest in six years.

Increasing remittances from migrants will have a positive impact on the increase in demand for housing, as buying a home is seen as an investment for the future. Immigrant groups can be divided into two categories:

- The first group includes all young immigrants who are educated, working and investing their income in the country where they have emigrated.

- The second group includes all migrants who work and bring their savings to Albania as they wish to return to their homeland in the future. It is precisely this group's income that affects the increase in demand for housing.

\subsection{Demographic Changes}

According to the data of the INSTAT the large cities have the highest net internal migration, even the only regions with positive rates, 16.1-19.3 respectively, for thousand inhabitants. In Figure no. 6, the gross migration rate measures the new inflows for every 1000 inhabitants, when positive, or the departures for every 1000 inhabitants, when the value is negative.

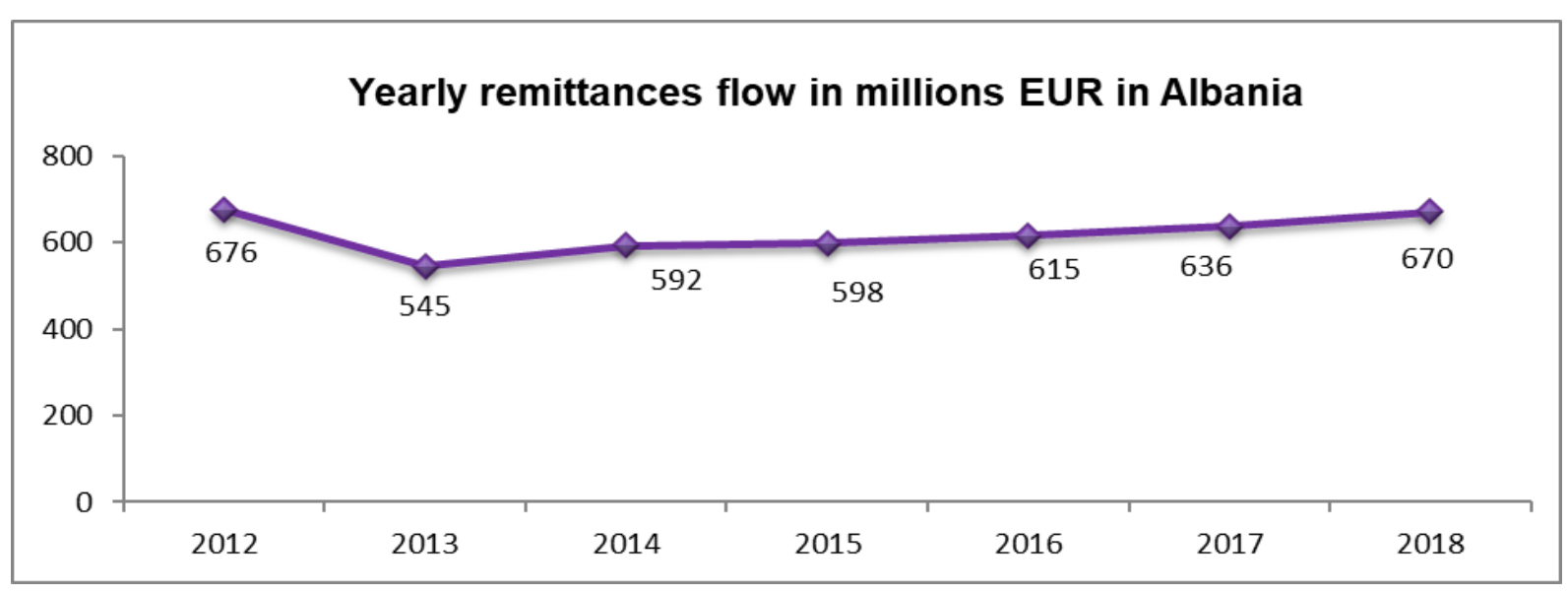

Source: Bank of Albania, $2018^{6}$

Figure 5. Flow of Remittances to Albania, 2012-2018 


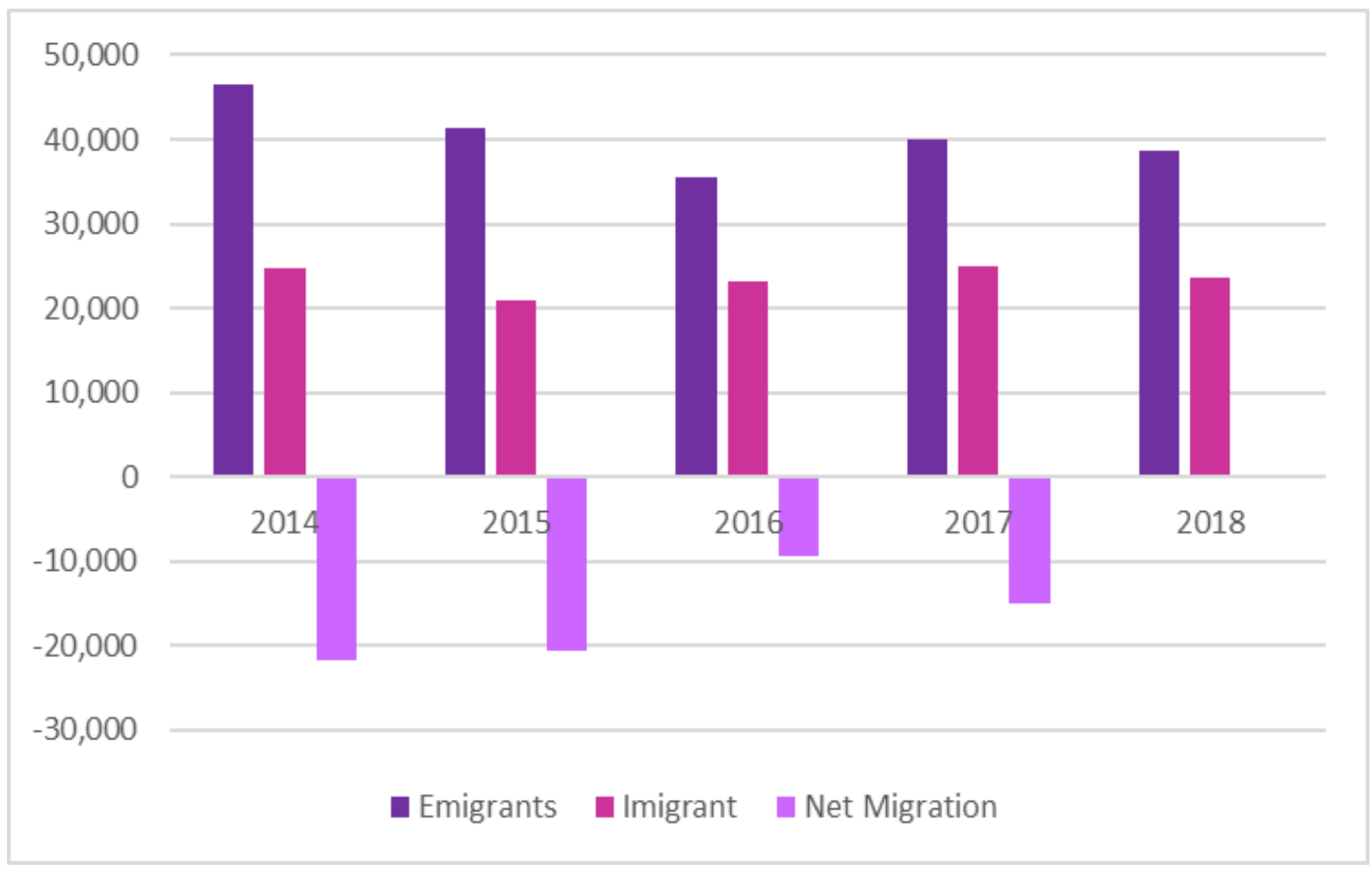

Source: INSTAT, $2019^{7}$

Figure 6. Number of emigrants, immigrants and net migration, 2014-2018

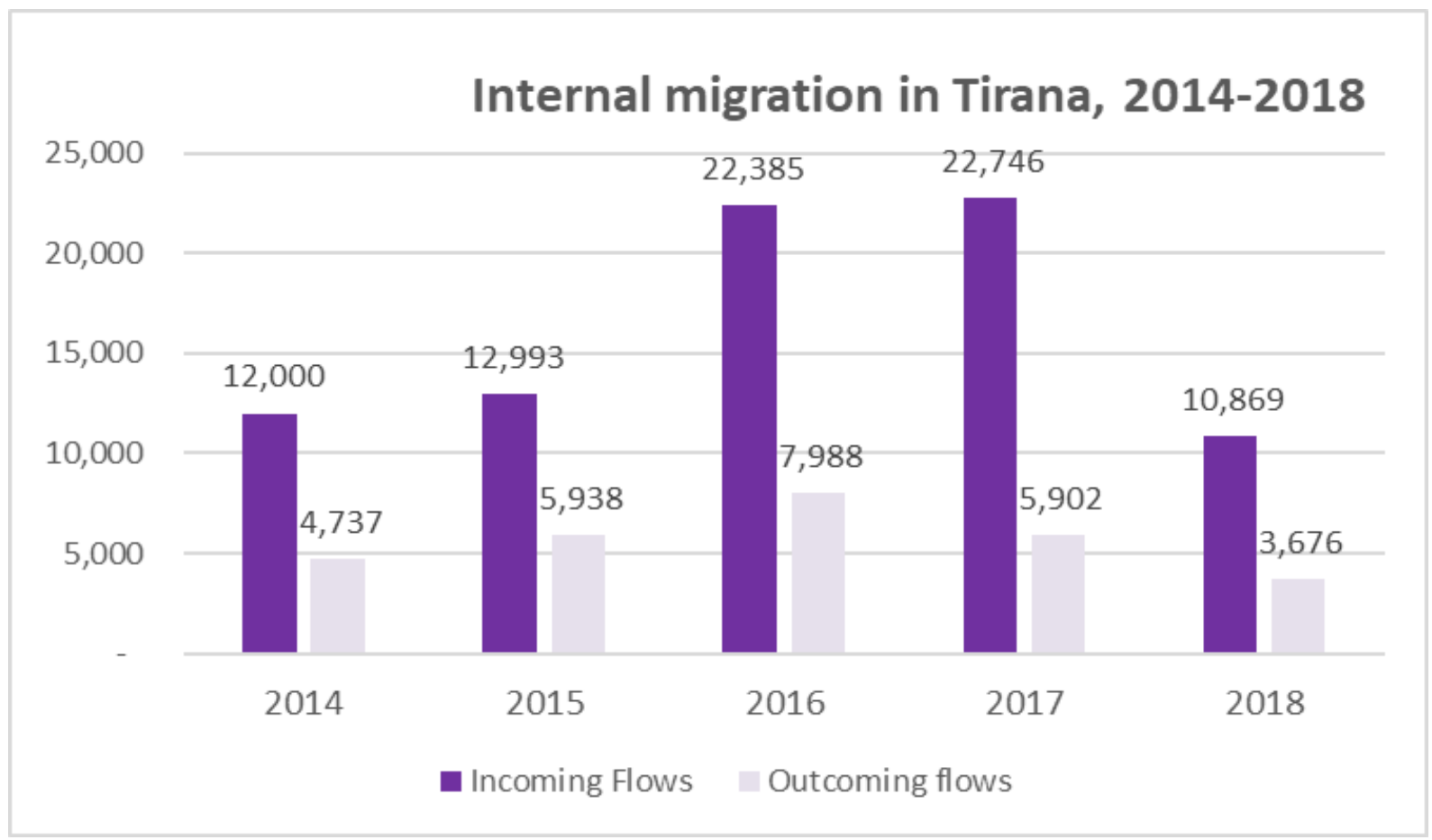

Source: INSTAT,2019

Figure 7. Internal migration in Tirana, 2014-2018 
In general terms there are 10 counties experiences more outflows of their populations than incomes and consequently have a negative net internal migration rate. If we judge the gross net internal migration rates, we will see that Gjirokastra, Dibra and Kukes are the regions with very low net internal gross migration rates, respectively -34.3 , $-33.7,-25,8$ per thousand inhabitants. Whereas, the Tirana district results in higher inflows than the outflows as noted in the Figure 7.

\section{Results and Findings from Data Processing}

For a more in-depth analysis of this paper in fulfillment of the purpose and objectives, the data base for the mentioned factors has been elaborated. The used data in the sample are extended in a period of 4 years (2016-2019) and on monthly basis. The sources used for the data obtained are Bank of Albania, INSTAT, EUROSTAT and authors' calculations. The processing and analysis of the data in this article to study the correlations between the factors was done by SPSS software version 21. An analysis of the data and econometric correlations will help us to reach important conclusions regarding the Anomalies of the Housing Market in Albania.

\subsection{Empirical Analysis and Results}

The analyses will consist of finding statistical relationships of individual factors as well: GDP/capita, Exchange rate, Interest rates in ALL, Interest rates EURO, Remittances and the loan levels of in EURO for home purchase.

Table 1. Correlations of individual factors and the level of Loans in EURO for home purchase

\begin{tabular}{|c|c|c|c|c|c|c|c|c|c|}
\hline \multicolumn{10}{|c|}{ Correlations } \\
\hline & & $\begin{array}{l}\text { Exchange } \\
\text { rate }\end{array}$ & $\begin{array}{c}\text { Interest rates } \\
\text { ALL }\end{array}$ & $\begin{array}{l}\text { Interest } \\
\text { rates } \\
\text { EURO }\end{array}$ & $\begin{array}{c}\text { Loans } \\
\text { Level_Euro }\end{array}$ & GDP/capita & \begin{tabular}{|c|}
$\Delta^{9}$ \\
Exchange \\
rate
\end{tabular} & $\begin{array}{c}\Delta \text { Loans } \\
\text { Level_Euro }\end{array}$ & $\begin{array}{c}\text { Remittance } \\
\text { inflows (Euro) }\end{array}$ \\
\hline \multirow{3}{*}{$\begin{array}{c}\text { Interest rates } \\
\text { ALL }\end{array}$} & $\mathrm{PC}$ & $.725 * *$ & 1 & .060 & $-.654 * *$ & $-.613 * *$ & .002 & -.024 & $-.478^{* *}$ \\
\hline & Sig. (2-t) & .000 & & .686 & .000 & .000 & .987 & .873 & .001 \\
\hline & $\mathrm{N}$ & 48 & 48 & 48 & 48 & 48 & 47 & 47 & 48 \\
\hline \multirow{3}{*}{$\begin{array}{l}\text { Interest rates } \\
\text { EURO }\end{array}$} & PC & .276 & .060 & 1 & -.225 & -.277 & .111 & $-.461 * *$ & $-.319 *$ \\
\hline & Sig. (2-t) & .057 & .686 & & .125 & .057 & .458 & .001 & .027 \\
\hline & $\mathrm{N}$ & 48 & 48 & 48 & 48 & 48 & 47 & 47 & 48 \\
\hline \multirow{3}{*}{$\begin{array}{c}\text { Loans } \\
\text { Level_Euro }\end{array}$} & $\mathrm{PC}$ & $-.899 * *$ & $-.654 * *$ & -.225 & 1 & $.645^{* *}$ & -.038 & $.309 *$ & $.565 * *$ \\
\hline & Sig. (2-t) & .000 & .000 & .125 & & .000 & .797 & .035 & .000 \\
\hline & $\mathrm{N}$ & 48 & 48 & 48 & 48 & 48 & 47 & 47 & 48 \\
\hline \multirow{3}{*}{ GDP/capita } & PC & $-.774 * *$ & $-.613 * *$ & -.277 & $.645 * *$ & 1 & $-.319 *$ & $.297^{*}$ & .141 \\
\hline & Sig. (2-t) & .000 & .000 & .057 & .000 & & .029 & .043 & .341 \\
\hline & $\mathrm{N}$ & 48 & 48 & 48 & 48 & 48 & 47 & 47 & 48 \\
\hline \multirow{3}{*}{$\begin{array}{c}\text { Remittance } \\
\text { inflows (Euro) }\end{array}$} & PC & $-.582 * *$ & $-.478 * *$ & $-.319 *$ & $.565 * *$ & .141 & $.296^{*}$ & .035 & 1 \\
\hline & Sig. (2-t) & .000 & .001 & .027 & .000 & .341 & .044 & .816 & \\
\hline & $\mathrm{N}$ & 48 & 48 & 48 & 48 & 48 & 47 & 47 & 48 \\
\hline \multirow{3}{*}{$\Delta$ Exchange rate } & $\mathrm{PC}$ & .089 & .002 & .111 & -.038 & $-.319 *$ & 1 & $-.373 * *$ & $.296^{*}$ \\
\hline & Sig. (2-t) & .552 & .987 & .458 & .797 & .029 & & .010 & .044 \\
\hline & $\mathrm{N}$ & 47 & 47 & 47 & 47 & 47 & 47 & 47 & 47 \\
\hline
\end{tabular}

Source: Authors's Calculations 
The rise in house prices is attributed to the increased demand for housing, which is affected by household incomes, political climate, mortgage loans, and real interest rates. Income is probably the most important economic variable to explain variations in consumer spending. But in the case of home purchase, income is treated in conjunction with mortgage loans to assess the effect they have on the price of housing [22]. In their study [5] they showed that Albania has the highest ratio in the region and beyond, between house prices and annual income per capita (Price/Income = 19.4). The level of income per capita is very low compared to the price of housing, so this factor is taken in combination with mortgage loans to buy houses. From the data on the currency of loans for home purchase, we notice that the predominant form of loans is that in the euro currency. The data used to study the behaviour of home purchase demand is the ending level of loans (monthly in euro) for home financing. The positive correlation coefficient (P.C. $=0.645)$ with a significance level of 0.01 indicates that with the increase in income per capita we have an increase in demand for mortgage loans in euro. [23] their study concluded that low-interest rates play an important role in the growth of mortgages because they increase the affordability and the desire to obtain mortgage loans. Referring to the table of correlations (no. 1), it is noted that the interest rate in Euro does not correlate with the level of loans in Euro. The same conclusion is found in the study of [15] and [5], where the correlation coefficient has the expected sign, but it turns out statistically insignificant.

In contrast to the statistically insignificant correlation with the interest rate in euro, there is a statistically significant negative correlation between the interest rate in ALL and the level of euro loans for house purchase (P.C = $-0.654 * *)$. From the analysis of these connections, an anomaly in the factors connected to mortgage loans is noted. To mention but a few reasons, (i) the difference between the currency the real estate market operates (in euro) and the currency with which incomes are received in our country (mostly in ALL), (ii) the lack of financial culture in the country and (iii) the lack of financial transparency in the income of individuals. In Albania, the declaration of financial resources has started recently, leaving informality to flourish, with a high concentration in the real estate market.

The study of the exchange rate provides a special significance for the effect it has on the volume of transactions in the real estate and financial markets. Its volatility is expected to affect both the demand for foreign currency loans and the purchasing power of individuals in the real estate market. The exchange rate stability in the sample taken in the study, accompanied by a moderately negative correlation between the processed variables $(\Delta$ Exchange rate and $\Delta$ Mortgage loans at the end of the month) of, $\mathrm{PC}=-0.373 * *$, indicates a presence of stable euro in the domestic economy. Moreover, the regulation of the real estate market in this currency coupled with a predominant mortgage credit level in the euro shows the high interest of the parties involved in these two sectors to operate in a currency that is not directly controlled by the country's monetary policy.

Albania continues to have a high rate of migration inside and outside the country. Demographic movements within the country have led to a concentrated development of the real estate market mainly in the capital and coastal areas, while emigration continues these days to bring considerable remittance inflows. Despite the positive correlation coefficient (P.C. $=0.565^{* *}$ ) between the two variables, this correlation remains to be studied. Referring to different studies for our country, most of the remittances go for daily living, at the same time some remittances circulate outside the financial sector through hand-to-hand remittances. The data and the positive correlation of the two variables lead to the conclusion that remittances may have an impact on the demand for housing, but the extent of forms of their use for investments in the real estate market remains unclear.

\subsection{Limitations of the Study}

- Data processing over a period more than 4 years would probably bring more accurate results.

- The inclusion of supply factors can improve the way this market works in Albania.

- The lack of continuous data increases the difficulty in comparing this market in time or markets of similar countries.

\section{Conclusions}

Referring to the literature used in this study as well as data obtained from secondary sources related to the study of economic phenomena in the housing market, and in particular the research of the determinants of the performance of housing prices, we tried to make a significant contribution to supplementing the literature on the case of Albania.

The authors' findings or other findings or even the descriptive analysis of our work on housing price performance and economic activity have identified that important factors are disposable income, mortgage lending level and interest rates.

An important conclusion of this paper is that the demand for housing has been underpinned by rising incomes, funding sources and exchange rate risk. Drawing on theoretical, empirical, and secondary data, it turns out that the performance of credit interest rates has a high impact on the fluctuation of house prices.

Referring to the empirical studies of the authors and the secondary sources used in the paper, it turns out that the use of foreign currency is a dominant factor. The exchange rate 
depreciation is expected to have a fall in house prices. The euro loan service will become more expensive and will significantly reduce mortgage lending and demand for housing.

This paper identified several important issues that are closely linked to the economic analysis of demand-side which are the determinants of the housing prices. Researching and studying these issues in the future by other authors would significantly improve the performance of house prices in the country.

The market demand for housing is a function of changes in house prices, household income, real credit rate, deposit interest rate, demographic developments and other factors related to housing market and the location of the apartment.

\section{REFERENCES}

[1] Anton L., "Konsiderata mbi vlerësimin e pasurive të paluajtshme në kushtet e sotme. Vlerësim dhe Modelim". https://www2.deloitte.com/ (accessed Aug. 20, 2019).

[2] Karl E.C., Robert J.S., "Is there a bubble in the housing market?", Cowles Foundation Paper. 1089, 2004, pp 299-362. http://www.econ.yale.edu/ shiller/pubs/p1089.pdf (accessed Aug. 25, 2019).

[3] Jonathan M.,Richard W. P., "Are Home Prices the Next "Bubble"?", Economic Policy Review, vol.10, no. 3, pp. 1-17, 2004. https://www.newyorkfed.org/research/epr/04v1 0n3/0412mcca/0412mcca.html (accessed Nov. 22, 2019).

[4] Alan G., "The Crisis", Brookings Papers on Economic Activity, vol. 1, pp. 201-261, 2010.https://www.brookings.e du/wp-content/uploads/2016/07/2010a_bpea_greenspan.pdf (accessed Jan. 5, 2020).

[5] Luciana K., Valbona Gj., Redian H., "Real Estate Market in Tirana", European Journal of Marketing and Economics, vol. 1, no. 2, pp. 45-56, 2018. DOI: http://dx.doi.org/10.26417/ej me.v1i2.p45-56

[6] Dag H. J., Bjørn E. N., "What drives house prices?", Economic Bulletin, vol 1, no. 05, pp. 29-41, 2005. https://www.norges-bank.no/globalassets/upload/publikasjo ner/economic_bulletin/2005-01/jacobsen.pdf (accessed Jan. $5,2020)$.

[7] Deniz I., Prakash L., "Global Housing Cycles", IMF Working Paper No. 12/217, 2012. https://www.imf.org/en/P ublications/WP/Issues/2016/12/31/Global-Housing-Cycles26229 (accessed Jan. 5, 2020).

[8] Ilir V., Erjona S., "Një Rishikim Mbi Kanalin E Kredisë Bankare Në Mekanizmin E Transmisionit Në Shqipëri", in Studime mbi Sistemin Bankar dhe Zhvillimin Ekonomik, Bank of Albania, 2018, pp. 51-76. https://www.bankofalban ia.org/rc/doc/Studime_mbi_sistemin_bankar_dhe_zhvillimi n_ekonomik_WEB_12486.pdf (accessed Jan. 5, 2020).

[9] Nathalie G., Mike K., Paul v d N., Christophe A., "Recent House Price Developments: The Role Of Fundamentals", ECO/WKP (2006)3, OECD. https://doi.org/10.1787/864035 447847
[10] Robert M. B., Sasha T., "Housing Market Systems in Reforming Socialist Economies: Comparative Indicators of Performance and Policy", European Journal Of Housing Policy, vol. 1, no. 2, pp. 257-289, 2001. DOI: $10.1080 / 14616710110083669$

[11] Sasha T., "Trends and Progress in Housing Reforms in South Eastern Europe", Council of Europe Development Bank, 2005. https://unece.org/DAM/hlm/documents/Publica tions/housingreforms.pdf (accessed Jan. 6, 2020).

[12]Enida B., Vasilika K., "How The Albanian External Environment Affect The Construction Industry", Annales Universitatis Apulensis Series Oeconomica, vol. 15, no. 1, pp. 295-309, 2013. http://oeconomica.uab.ro/upload/lucrari/152 0131/24.pdf (accessed Jan. 15, 2020).

[13] Kostas T., Haibin Zh., "What Drives Housing Price Dynamics: Cross-Country Evidence", BIS Quarterly Review, 2004, pp. 65-78. https://www.bis.org/publ/qtrpdf/r_qt0403f. pdf, (accessed Jan. 15, 2020).

[14] Ben B., Mark G., "Agency Costs, Net Worth, and Business Fluctuations", American Economic Review, vol. 79, no. 1, pp. 14-31, 1989. https://www.jstor.org/stable/1804770 (accessed Feb. 1, 2020).

[15] Erjona S., Gent H., "House Prices And Mortgage Loans Empirical Analysis For Tirana", Bulletin of the Bank of Albania, 2012, pp. 131-152. https://www.bankofalbania.org/ rc/doc/Bulletin_of_the_Bank_of_Albania_H_I_2012_6465_ 2_7333.pdf (accessed Feb. 1, 2020).

[16] Erjona R., "Mortgage Lending And House Prices In Albania -A Co-Integrated Analysis Based On VECM", Eastern Journal Of European Studies, vol. 5, no. 1, pp. 79-98, 2014. https://ejes.uaic.ro/articles/EJES2014_0501_REB.pdf (accessed Feb. 1, 2020).

[17] Yanbing Z. Xiuping H., Liang Z., "Monetary Policy And Housing Prices; A Case Study Of Chinese Experience In 1999-2010", BOFIT Discussion Papers No. 17, 2011. URL: https://helda.helsinki.fi/bof/bitstream/123456789/8138/1/16 9187.pdf (accessed Aug. 25, 2019).

[18] Liu Y., Hu Zh., "on Correlation between RMB Exchange Rate and Real Estate Price based on Financial Engineering", Systems Engineering Procedia, vol. 3, pp. 146-152, 2011. https://doi.org/10.1016/j.sepro.2011.11.020

[19] Balázs É., Dubravko M., "Determinants of House Prices In Central And Eastern Europe", Comparative Economic Studies, vol. 49, no. 3, 2007. https://doi.org/10.1057/palgrav e.ces. 8100221

[20] Boris H., "The Determinants Of Private Sector Credit In Industrialised Countries: Do Property Prices Matter?", BIS Working Paper No. 108, 2001. http://dx.doi.org/10.2139/ssr n.847404

[21] Anil K., Jeremy S., David W., "Monetary Policy and Credit Conditions: Evidence from the Composition of External Finance: Reply", The American Economic Review, vol. 83, no. 1, pp. 78-98, 1993. http://links.jstor.org/sici?sici=0002-8 $282 \% 2819930 \ldots$ O\%3B2-2\&origin=repec (accessed Aug. $25,2019)$.

[22] Win Lin Ch., Shih Y.C., " Hong Kong Housing Markets: Overview, Tenure Choice, and Housing Demand ", Journal of Real Estate Finance and Economics, vol. 10, pp. 7-21, 
1995. https://doi.org/10.1007/BF01099608 (accessed Apr. 5, 2021).

[23] Jose P., Robert Sh., " The Private Housing Market in Eastern
Europe and the CIS", UN Commission for Europe Discussion Paper No. 6, pp. 1-39, 2006. https://dx.doi.org/10.2139/ssrn.903119 (accessed Apr. 5, 2021). 